\title{
Analysis of noun (direct object) collocations with the high-frequency verb DO by Spanish students in an online learner corpus
}

\author{
Sidoní López Pérez ${ }^{1}$ Hanane Benali Taouis ${ }^{2}$
}

\begin{abstract}
This paper analyzes noun (direct object) collocations with the high-frequency verb do by Spanish university students in a computerized learner corpus that includes 155 participants and a total of 246 writing samples. The corpus includes the students' spontaneous written contributions to a compulsory online forum from the nonlinguistic subject, ICT Tools Applied to the Learning of English, included in the curriculum of the Degree in Early Childhood Education at Universidad Internacional de La Rioja (UNIR), from 2014-2015 to 2015-2016. The analysis reveals that these learners produce collocation errors with the high-frequency verb do in two different cases: 1) when they use do instead of make; and, 2) when they make use of $d o$ as an alternative to other verbs. Results show different underlying factors which are clearly interrelated. First, the students have problems to differentiate between $d o$ and make. Second, they make use of $d o$ with delexical constructions that require make and with causative make structures. Third, they make use of patterns from their mother tongue which are not always accurate in English. Finally, the students show low collocational awareness and competence. All these aspects suggest pedagogical implications for the teaching and learning of collocations with $d o$ which are also included in the paper.
\end{abstract}

Keywords: high-frequency verb; collocations; learner corpus; collocational competence; mother tongue influence.

\section{[es] Análisis de colocaciones de sustantivos (función de objeto directo) con el verbo de frecuencia $D O$ por estudiantes españoles en un corpus de aprendizaje online}

Resumen. Este artículo analiza colocaciones de sustantivos (función de objeto directo) con el verbo de frecuencia do por estudiantes universitarios españoles en un corpus de aprendizaje computarizado que contiene 155 participantes y un total de 246 muestras escritas. El corpus incluye las participaciones por escrito que los alumnos han realizado en un foro obligatorio de la asignatura no lingüística Herramientas TIC Aplicadas al Aprendizaje del Inglés, que es parte del currículo del Grado en Maestro en Educación Infantil en la Universidad Internacional de La Rioja (UNIR), en los cursos académicos 2014-2015 y 2015-2016. El análisis realizado demuestra que los estudiantes cometen errores de colocación con el verbo de frecuencia do en dos casos distintos: 1) cuando utilizan do en vez de make; y, 2) cuando hacen uso del verbo do como alternativa a otros verbos. Los resultados muestran distintos factores que están claramente interrelacionados. En primer lugar, los alumnos presentan dificultades para diferenciar entre el verbo do y make. En segundo lugar, utilizan do con construcciones léxicas que requieren del verbo make y con estructuras causativas que también requieren de dicho verbo. En tercer lugar, los alumnos hacen uso de estructuras que provienen de su lengua materna y que no siempre son correctas en inglés. Finalmente, los estudiantes muestran una competencia y conocimiento de colocaciones de nivel bajo. Todos estos aspectos traen consigo una serie de implicaciones pedagógicas para la enseñanza y el aprendizaje de las colocaciones con do que también pasamos a incluir en este artículo.

\footnotetext{
Department of Didáctica de la Lengua Inglesa, International University of La Rioja, sidoni.lopez@unir.net.

2 Department of Liberal Arts, The American University of the Middle East (Kuwait), hanane.ben-ali@aum.edu.kw.
} 
Palabras clave: verbo de frecuencia; colocaciones; corpus de aprendizaje; competencia colocacional; influencia de la lengua materna.

Contents. 1. Introduction. 2. Review of the literature. 2.1. Definitions and classification of collocations. 2.2. The importance of collocations for teaching and learning English. 2.3. Previous research on collocations. 3.1. Participants and the learner corpus. 3. The study. 3.2. Data and methodology. 3.3. Results and discussion. 4. Conclusions and pedagogical implications. 5. Limitations and further lines of investigation.

How to cite this article: López Pérez, S.; Benali Taouis, H. (2019) Analysis of noun (direct object) collocations with the high-frequency verb DO by Spanish students in an online learner corpus, in Complutense Journal of English Studies 27, 99-120.

\section{Introduction}

Many scholars have investigated the issue of collocation in learners of a foreign language, and studies have shown that collocations continue to be an area of difficulty for students of English as a Second Language (ESL). Different researchers have focused their analysis on the production of verb+noun collocations by university students of English (Altenberg and Granger, 2001; Juknevičienè, 2008; Luzón, 2011; Nesselhauf, 2003; Zinkgräf, 2008; Zhou, 2016). Among the multiple verbs analyzed in these studies, high-frequency verbs deserve special attention because they "are not only frequent and important, but also tend to be problematic for foreign language learners" (Zhou, 2016: 42). In this paper, we aim to throw some light on the use of one high-frequency verb collocations by Spanish university students that use English as a Medium of Instruction (EMI). In particular, the present study focuses on noun (direct object) collocations that occur with the high-frequency verb $d o$. The analysis is based on a comparable monolingual corpus, ENTECOR, which contains 470,088word tokens and is divided into two sub-corpora. More precisely, the present study focuses on the production of do+noun collocations in one of the components of the corpus that includes original and complete texts submitted by 155 students, with a total of 246 writing samples. Through a detailed analysis, we first aim at locating and identifying the typical errors in do+noun (direct object) collocations. Then we intend to analyze those collocation errors in order to trace some underlying factors related to collocational misuse. Finally, we provide some pedagogical implications which may be useful to improve the students' collocation competence and to enhance the teaching act in this area of Second Language Acquisition (SLA).

\section{Review of the literature}

\subsection{Definitions and classification of collocations}

Many researchers and scholars have provided different definitions for the notion of "collocation" from different theoretical frameworks. However, there is no general agreement among linguists, and it is quite challenging to form and provide a precise definition of the term. As Nesselhauf (2004) points out, the definition of "colloca- 
tion" has usually been adapted to the different aims and methods of the multiple investigations carried out by various scholars. The term "collocation" was first introduced by Palmer (1933: i), who defines a collocation as "a succession of two or more words that must be learned as an integral whole and not pieced together from its component parts". Some years later, it was developed as a technical term by Firth (1957: 182), who defines collocations "as actual words in habitual company". His definition is similar to the one provided by James (1998: 152), who also makes reference to collocations as "the other words any particular word normally keeps company with". Other scholars refer to collocations as combinations or co-occurrence of words. Such is the case of Lewis (1997: 44), who explained that "collocations are those combinations of words which occur naturally with greater than random frequency"; Nesselhauf (2003: 225), who talks about combinations of words whose restriction "is to some degree arbitrary"; O'Dell and McCarthy (2008: 4), who clearly state that "collocation means a natural combination of words; it refers to the way English words are closely associated with each other"; Parrott (2010: 125), who says that collocations are "two-word combinations where there is a restricted choice of which words can precede or follow which"; and Sinclair (1991: 170), who defines collocations as "the occurrence of two or more words within a short space of each other in a text". After taking all these definitions into consideration, it seems appropriate to define collocations that can be adapted to the goals of this investigation. Therefore, we consider collocations as the set of two or more words which have an arbitrary restriction in their commutability and that must occur and combine in order to produce accurate sentences from a grammatical point of view.

Regarding the classification of collocations, they have been approached from two different perspectives: the Firthian approach, or the "statistically oriented approach" (Herbst, 1996: 380), or the "frequency-based approach" by Nesselhauf (2004), which is the co-occurrence of words at a certain distance, although it also needs to be said that such co-occurrence must be statistically significant; and, the "significance oriented approach" (Herbst, 1996: 380) or "phraseological approach" (Nesselhauf, 2004), which concerns itself with classifying schemes of phraseological units according to their varying degrees of fixedness. In other words, collocation is considered as one particular type of phraseological unit and one type of word combination, which is partly fixed (Nesselhauf, 2004). In the present study, we are applying criteria from both approaches, which means that we are making use of a mixed perspective or "the best of two worlds?" as Gyllstad (2007) indicates and explains in his doctoral dissertation. On the one hand, we use the "frequency-based approach" in order to identify collocations with the high-frequency verb do in the learner corpus, and on the other hand, we make use of the "phraseological approach" so as to make a more manual and restricted selection of those collocations by focusing solely on noun (direct object) collocations with $d o$. In particular, we are interested in using the "phraseological approach" for the selection of collocations in the corpus because according to this perspective, collocation is used to denote a type of word combination rather than the co-occurrence of words at a certain distance. In this classification, collocations are usually defined as word combinations that have an arbitrary restriction on the commutability of their elements (Juknevičienè, 2008). Therefore, the verb in do homework cannot be replaced by the synonymous make.

In addition, and as said before, in the present study we focus on noun (direct object) collocations that occur with the high-frequency verb $d o$. As some studies re- 
veal, although high-frequency verbs are usually acquired in the first stages of learning English, they continue to be difficult and problematic for learners, even at the advanced level (see Altenberg and Granger, 2001; Hasselgren, 1994; Källkvist, 1998; Nesselhauf, 2005). In fact, the researchers that conducted these studies have concluded that learners of English with different mother tongue backgrounds overuse this type of verbs. In particular, Hasselgren (1994: 237) refers to these verbs as "lexical teddy bears", and she refers to the fact that ESL learners have a dependence on them. This, however, "only increases the already numerous opportunities for learners to use these verbs erroneously" (Hugon, 2008: 72). These results are consistent with the present study since the examples collected from the learner corpus reveal that the students overuse the high-frequency verb do in cases in which the verb make or other different verbs are required. This gives rise to a series of miscollocations with do when this verb is followed by noun (direct object) collocations that certainly need to combine with other verbs in order to make sense and be grammatically and semantically accurate.

\subsection{The importance of collocations for teaching and learning English}

Many scholars and researchers have acknowledged the importance of collocation in language teaching and learning. As Hill (2000: 53) points out, "collocations are found in up to $70 \%$ of everything we say, hear, read or write", and they are probably the most common and most representative of English multi-word expressions (Lewis, 2000). Collocations are usually considered to be a fundamental part of second language (SL) lexical development (Ellis, 1996), and "an important aspect in vocabulary acquisition" (Duan and Quin, 2012: 1891). Different scholars and linguistics have come to agree that teaching vocabulary is as significant, or even sometimes more important than, teaching grammar structures. This view stems partly from Lewis's (1993) lexical approach, which basically focuses on the premise that a language is made up of lexical units, which consist of words, chunks formed by collocations, and fixed phrases. In his view, words do not exist in isolation and chunks are the building blocks of language; therefore, it is important to know which word goes with which other word. Lewis (1997: 204) puts even more emphasis on collocations after explaining that "instead of words, we consciously try to think of collocations, and to present these in expressions. Rather than trying to break things into ever smaller pieces, there is a conscious effort to see things in larger, more holistic, ways". This is why he encourages teachers to make L2 learners notice and observe collocations through different exercises and activities because they "ensure quicker and more carefully-formulated hypotheses about L2, and so aid acquisition, which is based on a constantly repeated Observe-Hypothesise-Experimental cycle (Lewis, 1997: 52).

Besides increasing the mental lexicon, learning collocations also develops fluency (Károly, 2005) and "is an integral part of acquiring proficiency in the target language" (McCarthy, 2018). In the same line, other scholars emphasize the fact that collocations enable L2 learners of English to improve their oral and written communication and production. Nation (2001) considers collocations as a central aspect of communicative competence, whereas linguists such as Boers and Lindstromberg (2009) and Durrant (2008) acknowledge the importance of collocational competence for language production and reception. Brown (1974) indicates that learning collo- 
cations helps learners improve their oral fluency, listening comprehension and reading speed. He also highlights that teaching collocations allows learners to be aware of language chunks which are generally used by native speakers of English both in speech and writing. James (1998: 152) also shares a similar view when making reference to the significant contribution that collocational conventions of a Foreign Language (FL) make to "one's idiomaticity and nativelikeness". Wray (2000: 479) supports this idea after highlighting the importance of the teaching of "formulaic sequences", which include idioms, collocations and sentences frames, "because they seem to hold the key to native-like idiomaticity". In other words, English is said to be more idiomatic or similar to the way it is spoken by native speakers when learners master collocations. This perspective can also be found in the Oxford Collocation Dictionary for Students of English (2007), which clearly indicates that collocation will help learners speak and write in English in a more natural way and sound native-speaker like. As Qader (2018: 51) explains, the knowledge of collocations is highly important in the production of language since "this experience enables learners to come across as natives, make natural choices and also process language accurately and fluently in real-time situations". At the same time, studying collocations can also help improve and learn grammar. Both Hill (2000) and Lewis (2000) agree that by learning language chunks, which contain specific grammatical structures, learners will be better able to acquire the grammatical pattern contained in the collocation. Also, Hill (2000) also highlights the importance of collocation knowledge in order to develop accuracy of expression. As Wu (2010:17) explains, this is mainly due to the fact that learners often use long and awkward sentences in both speech and writing "because they are unable to express complex ideas lexically". However, in many cases these sentences could be replaced by collocations.

All in all, and as Nesselhauf (2003: 223) points out, collocations "are an important part of native-speaker competence, and that they, therefore, should be included in foreign and second language teaching is widely acknowledged today". In the present study, the students have shown a low collocation competence when making use of do with noun (direct object) collocations, and as a result, they produce multiple errors that make their language sound awkward, unnatural and grammatically incorrect. Therefore, it becomes a necessity to teach them about the possible collocations they can use with the high-frequency verb $d o$ and establish some differences regarding those collocations with make.

\subsection{Previous research on collocations}

Many scholars have investigated the issue of collocation in a foreign language setting. In the case of English, collocations are considered to be a problematic area for ESL learners and different studies have been carried out in order to analyze collocation errors among students from different linguistic backgrounds. Although some researchers have focused on data extracted from collocations tests and written assignments provided to ESL students (see Jaén, 2007; Martynska, 2004; Shitu, 2015; and Yamashita and Jiang, 2010), most scholars have centred their research on collocations on the written samples obtained from learner corpora. To cite a few examples, Altenberg and Granger (2001) analyze collocations with make by Swedish and French-speaking learners with data extracted from the International Corpus of Learner English (ICLE) database. 
Similarly, Nesselfhauf (2003) makes use of the German subcorpus of ICLE in order to analyze verb+noun collocations in the written productions of German-speaking learners of English. Juknevičienè (2008) also investigates the use of collocations with high-frequency verbs by Lithuanian learners of English in The Lithuanian Component of the International Corpus of Learner English (LICLE) and compares it with data from The Louvain Corpus of Native English Essays (LOCNESS). In the case of Zinkgräf (2008), she includes the written production of 102 Spanish speaking students in her study of verb+noun miscollocations with data extracted from a manually-compiled corpus at a university in Argentina. Luzón (2011) conducts similar research by analyzing atypical verb+noun combinations in a corpus of technical English texts written by Spanish Engineering students. In his doctoral dissertation, Hong (2014) also focuses on collocation errors in a learner corpus that includes 117 pieces of written texts by Chinese ESL learners. More concretely, Zhou (2016) analyzes collocations with the high-frequency verb have by Chinese learners of English in a learner corpus that consists of 633 written compositions. Besides, Sadeghi and Panahifar (2013) focus their research on the analysis of collocation errors by Iranian learners of English from a corpus that consists of 30 spoken productions.

While the publication of these studies on collocational competence is from every point of view praiseworthy, most scholars focus on the analyses of different types of collocations without specifically centring on miscollocations that occur with certain verbs which are often confusing for learners of English (e.g. do and make). Of all the studies mentioned above, only three of them focus on collocations with high-frequency verbs (Altenberg and Granger, 2001; Juknevičienè, 2008; and Zhou, 2016), and only two of them analyze collocations with a specific high-frequency verb (Altenberg and Granger (2001) focus on make and Zhou (2016) centres on have). Therefore, for this study, we decided not to produce a list of miscollocations, but rather focus on noun (direct object) collocations that occur with the high-frequency verb $d o$. Collocations with this kind of verb have rarely been approached, and our study reveals that the students continue to have problems with $d o$ when collocating with different nouns that serve as direct objects. At the same time, it can also be perceived that research on collocations generally includes ESL or EFL learners as participants and the investigations are based on specific written assignments or collocation tests as instruments for data collection. By contrast, nonlinguistic subjects and the spontaneous language production of students have not received much attention. Thus, the importance of the present study lies in the fact that it analyzes noun (direct object) collocations with do in the learners' natural writing contributions to a compulsory online forum from the nonlinguistic subject, ICT Tools Applied to the Learning of English, which belong to a computerized learner corpus at Universidad Internacional de La Rioja.

\section{The study}

\subsection{Participants and the learner corpus}

The learner corpus used for this study is a monolingual comparable corpus, ENTECOR, which is composed of two sub-corpora, TICOR and SECOR. It includes 
the writing productions of 786 students from Universidad Internacional de La Rioja (UNIR) and a total of 527,099 tokens and 13,148 types. The first sub-corpus, TICOR, consists of two more components: ICT, which includes the texts produced spontaneously by 155 students in an online forum from a subject within the framework of the Degree in Early Childhood Education, and TIC, which contains the writing productions of 511 learners in another online forum from another subject in the Degree in Primary School Education. The second sub-corpus, SECOR, is composed of the writing productions of 120 learners in an online forum from a subject in the framework of the Master's Degree in Secondary Education. For this study, we have focused on the first component of the TICOR sub-corpus, ICT, which includes original and complete texts submitted by 155 students, with a total of 246 writing samples, 4,816-word types and 107,042-word tokens. These samples belong to the multiple contributions of the students to a compulsory forum of the nonlinguistic subject, ICT Tools Applied to the Learning of English, which used English as a Medium of Instruction (EMI) and was totally taught in an online environment. In this forum, the learners write about their opinion and points of views regarding a topic suggested in the syllabus and debate among themselves, without any intervention by the professor. In this case, the students write about the use and effectiveness of authentic materials and already-made materials, and the task requirements include a maximum of three graded contributions where the learners can get the full mark by participating three times or lose part of their mark for fewer participations. Regarding the students' level of English, although no detailed information has been collected individually, the learners are required to have between A2 and B1 levels according to the Common European Framework of Reference for Languages.

\subsection{Data and methodology}

The corpus was analyzed with the Concordance tool of the freeware concordance program Antconc (3.3.4). The first step was to locate all the occurrences of the high-frequency verb $d o$ in the corpus. For the purpose of this, we typed the string $d^{*}$ in the search box of the Concordance tool and we assigned three different levels to generate lines in Key Word in Context (KWIC): Level 1R; Level 2R, and Level $3 \mathrm{R}$, which means that only collocations with collocates up to 3 positions to the right of the node were extracted. Whereas the string $d^{*}$ allowed us to locate the different inflected forms of the verb and its negative forms (do, does, did, done, don't and doesn't), the levels in the KWIC Sort made it possible for us to locate all the words that collocate with and follow $d o$ with all its different variants. The second step was to read the concordance lines very carefully in order to eliminate irrelevant cases (e.g. when do is used as an auxiliary verb in both negative and interrogative sentences, and when it is used to emphasize an affirmative sentence (emphatic do), and so as to locate only those sentences which included noun (direct object) collocations after the verb. The third step was to extract all those sentences with collocations manually from the corpus, and the last step was to scrutinize all those lines very carefully in order to identify and locate instances of miscollocations with do regarding noun (direct objects) (e.g. do an approach, do a movement). All these details are shown in the table below. 
Table 3. DO and its collocations in the learner corpus.

\begin{tabular}{|l|l|}
\hline \multicolumn{1}{|c|}{ Corpus } & \multicolumn{1}{c|}{ ENTECOR } \\
\hline Sub-corpus & TICOR \\
\hline Component & ICT \\
\hline Participants & 155 \\
\hline Writing samples & 246 \\
\hline Word types & 4,816 \\
\hline Word tokens & 107,042 \\
\hline Hits retrieved by the string $d^{*}$ & 2345 \\
\hline Occurrences of $D O$ and its variants & 732 \\
\hline DO+NOUN (Direct Object) Collocations & 164 \\
\hline
\end{tabular}

As for the examples extracted from the corpus, all of them are verbatim and will be included in tables that provide the following details and codes employed in the learner corpus: the hit number, the example, the student identification number, the source text (TO), the language (English: EN), the subject (ICT), and the forum of all the sections of this subject that contains two compulsory forums during the academic year (letter A makes reference to forum 1, whereas letter B indicates forum 2). As we needed to read full sentences, and in some cases, even full paragraphs to make sure we understand the context and what we are analyzing is a clear error, we include in our analysis examples of full sentences to clarify the cases for the readers and demonstrate the errors in context. In addition, all collocational errors will be presented in bold, and the correct form will also be included after each example. Apart from this, although this study focuses on the pattern verb (do) + noun (direct object) collocations, we have also included those instances (they are just a few) in which the noun (direct object) appears before the verb because this also implies a collocation error and because sometimes the students make use of this structure with the past participle form done (e.g. I can say that material which is already*done; all the contributions that my partners have *done).

\subsection{Results and discussion}

The current analysis is focused on miscollocations with the high-frequency verb $d o$. We specifically analyze this verb when it forms collocations of the pattern verb + noun (direct object) (e.g. do a job, do a favour). After carefully analyzing the different sentences in which the verb do appears with noun (direct object) collocations in the corpus, we were able to identify 42 collocational errors out of 164 collocations, which means that $d o$ is incorrectly used in $25.60 \%$ of the cases. Although this percentage is not very high, it deserves our attention because it clearly indicates that collocations with the high-frequency verb $d o$ continue to pose significant difficulties for Spanish students. For this, and in order to analyze the acceptability of such collocations, we made use of the LTP Dictionary of Selected Collocations (1997), 
the Oxford Collocation Dictionary for Students of English (2002) and the British National Corpus (BNC). Besides, and according to the multiple miscollocations that we found in the corpus, we classified all the incorrect collocations into two different types of mistakes:

1. Those in which do is used instead of make, which at the same time is divided into three sub-types, following three of the eight major categories of use for make proposed by Altenberg and Granger (2001):

a. Do with the meaning of producing something as a result of creation (e.g. do my own resources, do our genuine materials).

b. Do with delexical structures (e.g. do an approach, do an effort).

c. Do with causative structures (e.g. doing my classes much easier, do the teacher's role easier).

2. Those in which $d o$ is used as an alternative to other verbs.

Table 4 illustrates this classification and provides the number of collocational errors for each type and the total number of errors in the learner corpus.

Table 4. Classification of collocational errors with the verb $D O$ in the learner corpus.

\begin{tabular}{|c|c|c|c|}
\hline \multicolumn{3}{|c|}{ Use of $\boldsymbol{D O}$ instead of $M A K E$} & Use of $\boldsymbol{D O}$ as an alternative to OTHER VERBS \\
\hline $\begin{array}{l}\text { Produce something } \\
\text { (result of creation) }\end{array}$ & $\begin{array}{l}\text { Delexical } \\
\text { structures }\end{array}$ & $\begin{array}{l}\text { Causative } \\
\text { structures }\end{array}$ & 11 \\
\hline 14 & 13 & 4 & Total number of errors: 11 \\
\hline \multicolumn{3}{|c|}{ Total number of errors: 31} & 42 \\
\hline \multicolumn{3}{|c|}{ Total number of COLLOCATIONAL ERRORS in both types } \\
\hline \multicolumn{3}{|c|}{4} \\
\hline
\end{tabular}

\subsubsection{Use of $D O$ instead of $M A K E$}

As the data in Table 4 displays, the first type of mistakes accounts for those instances in which the high-frequency verb do is used with collocations in which the verb make should be used. In other words, the overuse of $d o$ with collocations that require make accounts for the most frequent type of mistake in the learner corpus. In this case, 31 wrong uses of $d o$ were identified out of 42 collocational errors, which means that $d o$ (instead of make) is misused in $73.80 \%$ of the cases. As indicated above, these collocational errors were classified into three different categories.

The first one refers to the use of $d o$ with the meaning of producing something as a result of creation, which is one of the uses and meanings provided and offered by make (Altenberg and Granger, 2001). According to our findings in the learner corpus, this category accounts for the major number of errors in this first kind of mistakes, that is, 14 collocational errors out of 31 , which is almost half of the mistakes in this first type $(45.16 \%)$. The following examples illustrate these typical errors: 
Table 5. Use of DO instead of MAKE in the learner corpus.

\begin{tabular}{|c|c|c|c|}
\hline Hit number & Examples & Correct form & Student ID \\
\hline 570 & $\begin{array}{l}\ldots \text { for a teacher }[\mathrm{sic}] * \text { do his } \\
\text { own activities } \ldots\end{array}$ & $\begin{array}{l}\text { for a teacher to make his/her } \\
\text { own activities }\end{array}$ & 40TOENICTB \\
\hline 697 & $\begin{array}{l}\text { I can say that material [sic] } \\
\text { which is already *done is } \\
\text { generic }\end{array}$ & $\begin{array}{l}\text { the material which is already } \\
\text { made or already-made } \\
\text { material }\end{array}$ & 82TOENICTB \\
\hline 699 & $\begin{array}{l}\text { The material which we find } \\
\text { *done ... }\end{array}$ & $\begin{array}{l}\text { the material which is already } \\
\text { made or already-made } \\
\text { material }\end{array}$ & 66TOENICTB \\
\hline 949 & $\begin{array}{l}\text { Sometimes I *do my own } \\
\text { resources ... }\end{array}$ & make my own resources & 19TOENICTB \\
\hline 1273 & $\begin{array}{l}\ldots \text { we had to } * \text { do our own } \\
\text { genuine materials }\end{array}$ & $\begin{array}{l}\text { make our own genuine } \\
\text { material }\end{array}$ & 34TOENICTB \\
\hline 1277 & $\begin{array}{l}\ldots \text { if we } * \text { did our own } \\
\text { material ... }\end{array}$ & made our own material & 82TOENICTB \\
\hline 1279 & $\begin{array}{l}\ldots \text { we will * do our own } \\
\text { material ... }\end{array}$ & make our own material & 147TOENICT \\
\hline 1333 & $\ldots$ the materials we can $*$ do $\ldots$ & the materials we can make & 20TOENICTB \\
\hline 1567 & $\begin{array}{l}\ldots \text { they would } * \text { do the activities } \\
\text { according to the needs of each } \\
\text { school and children. }\end{array}$ & make the activities & 31TOENICTB \\
\hline 1576 & $\begin{array}{l}\text {.. you can take two or three } \\
\text { [activities], mix them and *do } \\
\text { the activity that you need. }\end{array}$ & make the activity & 82TOENICTB \\
\hline 1600 & $\begin{array}{l}\ldots \text { I also *did the } \\
\text { illustrations } \ldots\end{array}$ & made the illustrations & 113TOENICTB \\
\hline 1659 & $\begin{array}{l}\text { Maybe the teachers haven't time } \\
{[\text { sic] for }[\text { sic] *do their genuine }} \\
\text { materials ... }\end{array}$ & $\begin{array}{l}\text { making their genuine } \\
\text { materials }\end{array}$ & 79TOENICTB \\
\hline 1660 & $\begin{array}{l}\ldots \text { the teacher must to }[\mathrm{sic}] * \mathrm{do} \\
\text { their }[\mathrm{sic}] \text { own materials and } \\
\text { resources } \ldots\end{array}$ & $\begin{array}{l}\text { the teacher must make his/her } \\
\text { own materials and resources }\end{array}$ & 43TOENICTB \\
\hline 1717 & $\begin{array}{l}\ldots \text { is that by *doing these } \\
\text { materials ... }\end{array}$ & making these materials & 11TOENICTB \\
\hline
\end{tabular}

In these sentences, the students make use of the verb do with noun (direct object) collocations when making reference to creating or producing something. This use is not accurate, since English grammar requires the use of the high-frequency verb make when referring to "produc[ing] something, often using a particular substance or material" (Cambridge Dictionary Online, 2019). In the corpus, the learners are 
talking about creating their own materials, resources and activities; therefore, the verb make should be used with the noun (direct object) collocations that come after it. In particular, we have located 14 examples in which the use of do is wrong because the learners rely on it to talk about things that they produce or create. Examples include the word material (s), which the students collocate with do in 9 sentences; the noun activities, which combines with do in 2 sentences; the word resources, which is used with do in 2 sentences; and the noun illustrations, which collocates with $d o$ in 1 sentence. Even though some of these words (e.g. activities) can indeed collocate with $d o$ when making reference to the process of acting or performing something (e.g. we did a listening activity, and it was quite difficult to get the right answers), it is wrong to collocate do with nouns when we talk about things that we produce or create. This indicates that our students find it difficult to differentiate between do and make, which are rendered in Spanish by a single word (e.g. hacer). As the examples reveal, it is clear to the learners that they must use the verb hacer in those sentences, but since hacer has two different verb forms in English (do and make), whether to choose one or the other becomes an arduous task for them. In this case, the students have resorted to the use of $d o$ without realizing or knowing that this verb cannot be used to talk about producing or creating something. This is because in English " $d o$ focuses on the process of acting or performing something", whereas "make emphasizes more the product or outcome of an action" (Cambridge Dictionary Online, 2019). This draws attention to the need to make the learners totally aware of the differences between do and make in the English language. On the other hand, it is important to bear in mind that in spoken English it is possible to use do with the meaning of producing or creating when the verb is used "with nouns such as copy, design, drawing, painting, especially in informal speech" (Cambridge Dictionary Online, 2019). However, these words are not used with do by the students in the learner corpus and the rule does not apply in the sentences that they write.

Alternatively, it would be possible to use other verbs which also make reference to the process of producing or creating something, and that could also be appropriate for the sentences that our students write. For example, in the case of the word $m a$ terial, the LTP Dictionary of Selected Collocations (1997) suggests the use of verbs such as "arrange" and the Oxford Collocation Dictionary for Students of English (2007) recommends the verb "produce" among others. As for the noun resource, the LTP Dictionary of Selected Collocations (1997) suggests the use of verbs such as "build up" and "develop", whereas the Oxford Collocation Dictionary for Students of English (2007) recommends verbs such as "provide". Regarding the verb "create", although it does not appear as a collocate for material and resource in the dictionaries mentioned above, it is a synonym for make and it certainly appears with these words in the $B C N$; therefore, the verb create could certainly be used in the sentences above (e.g. create our own material, create our own activities/resources, create illustrations). The use of these other verbs has been highlighted by Luzón (2011) in her study of verb+noun combinations in a corpus of English technical writing by Spanish students. She concluded that although in some examples do and make were used instead of the other, in most instances, the use of sub-technical verbs such as "produce" would be more appropriate.

The second category in the first type of mistakes is related to the so-called delexical structures. These constructions consist of a delexical verb (e.g. do, make, have, give) which is followed by a noun group (Sinclair, 1990). Delexical verbs, also 
known as "light verbs" (Huddleston and Pullum, 2002), are usually referred to as verbs which when used with particular nouns have very little meaning of their own (Sinclair, 1990). In these structures, most of the meaning is found in the noun, not in the verb (e.g. do a favour, do homework). In the learner corpus, the students make use of $d o$ with delexical structures that require make. The wrong choice of verb, in this case, accounts for the second most frequent type of mistake in this first classification of mistakes. Thirteen collocation errors were identified out of 31 mistakes, which indicates that $d o$ is used incorrectly in $41.93 \%$ of the cases. Table 6 below illustrates this type of mistake.

Table 6. Use of $D O$ with delexical structures in the learner corpus.

\begin{tabular}{|c|c|c|c|}
\hline Hit number & Examples & Correct form & Student ID \\
\hline 6 & $\begin{array}{l}\text { I am sure I will can }[\mathrm{sic}] \text { to }[\mathrm{sic}] \\
* \text { do a better using and ... }\end{array}$ & make better use & 112TOENICTB \\
\hline 145 & $\begin{array}{l}\ldots \text { help students to } * \text { do an } \\
\text { approach to the language ... }\end{array}$ & make an approach & 118TOENICTA \\
\hline 147 & $\begin{array}{l}\ldots \text { it is necessary to } * \text { do an } \\
\text { effort ... }\end{array}$ & make an effort & 120TOENICTA \\
\hline 595 & $\begin{array}{l}\text {.. all the contributions that my } \\
\text { partners have *done. }\end{array}$ & $\begin{array}{l}\text { all the contributions that my } \\
\text { partners have made }\end{array}$ & 106TOENICTA \\
\hline 642 & $\begin{array}{l}\ldots \text { all the cuts that have been } \\
* \text { done in education... }\end{array}$ & $\begin{array}{l}\text { all the cuts that have been } \\
\text { made }\end{array}$ & 11TOENICTB \\
\hline 678 & $\begin{array}{l}\ldots \text { related to the comment which } \\
\text { have } * \text { done [Student name] }\end{array}$ & $\begin{array}{l}\text { to the comment which/that } \\
\text { [Student name] has made }\end{array}$ & 03TOENICTA \\
\hline 775 & $\begin{array}{l}\text { The post that [Student name] has } \\
\text { *done... }\end{array}$ & $\begin{array}{l}\text { The post that [Student name] } \\
\text { has made }\end{array}$ & 02TOENICTB \\
\hline 1285 & $\begin{array}{l}\ldots \text { we will *do our own } \\
\text { selection ... }\end{array}$ & make our own selection & 147TOENICT \\
\hline 1578 & $\begin{array}{l}\ldots \text { we, as teacher [sic], must } * \text { do } \\
\text { the adaptations to use them... }\end{array}$ & must make the adaptations & 63TOENICTB \\
\hline 1591 & $\begin{array}{l}\ldots \text { if the teacher has *done the } \\
\text { effort to... }\end{array}$ & has made the effort & 10TOENICTB \\
\hline 1592 & $\begin{array}{l}\ldots w e \text {, as teachers, should *do } \\
\text { the effort to... }\end{array}$ & should make the effort & 135TOENICT \\
\hline 1951 & $\begin{array}{l}\text {.. I think that the only use I can } \\
\text { *do with already made material }\end{array}$ & the only use I can make of & 57TOENICTB \\
\hline 1974 & $\begin{array}{l}\text {... to take care of any movement } \\
\text { that they *do with the [sic] ICT } \\
\text { tools ... }\end{array}$ & $\begin{array}{l}\text { any movement that they } \\
\text { make }\end{array}$ & 55TOENICTA \\
\hline
\end{tabular}


As these sentences reveal, the students are not aware of or do not possess sufficient knowledge about the delexical structures that require the use of make. These collocations do not follow any rule, and the meaning of the verb does not really have to do with the meaning of the noun that comes after it. In fact, this type of collocations bears little semantic resemblance to the meaning that is found initially in dictionaries. In the case of make the effort, which is the correct form for the miscollocations *do an effort, has *done the effort and should *do the effort (hits 147, 1591 and 1592, respectively), the delexical structure is composed of two different words. On the one hand, the verb make is generally used when producing or creating something, whereas the noun effort makes reference to a "physical or mental activity needed to achieve something" (Cambridge Dictionary Online, 2019). However, the delexical construction make the effort is used when "do[ing] something even though you do not want to or you find it difficult" (Macmillan Dictionary, 2019). This highlights the need to teach the learners about the meaning of delexical structures and the right verb that collocates with them. This is especially important if we take into consideration the fact that in Spanish, the verbs $d o$ and make have only one verb form (hacer). Adding to this is the absence of a generative rule that allows the learners to decide between do and make in delexical constructions in English. As a consequence, the students are not sure about which verb collocates with these expressions and they choose the one they think is the most appropriate. The result is the production of collocation errors with delexical structures that require make instead of do. As shown in the sentences above, the learner corpus includes several examples of wrong delexical constructions (e.g. *do a better using, *do an approach, *do an effort, *do contributions, *do cuts, do comments, *do posts, *do a selection, *do adaptations, *do a movement). In other words, the students use the verb do with many nouns that only collocate with make when used in these delexical structures.

Besides making mistakes when selecting the right verb that collocates with delexical structures, the students also commit errors when using the noun that collocates with the verb and sometimes with the preposition that comes after the noun. Therefore, it becomes relevant to teach the learners about the right word that comes after the verb so that they can produce grammar structures which are correct and accurate. A clear example can be found in the sentences *do a better using and advantages about $T I C^{3}$ [sic] (hit 6) and the only use I can *do with ... (hit 1951). In the first structure, the student uses the indefinite article $a$ after the verb, which is not necessary because the delexical construction make use of does not require any type of article. Also, the learner makes use of the gerund form using, which seems to be used as a noun. This is incorrect since use is one of those words that functions as both a noun and a verb. Almost at the very end of the phrase, the student uses the preposition about, which does not make sense either, and it is not the right preposition to use with the delexical structure make use of. Therefore, a better rendition for this sentence would be make better use of ICT and its advantages. Another wrong use of the preposition when using the delexical structure make use of is also found in the

The use of the term ICT and other different variants in the corpus have been analyzed in previous research by Torrado-Cespón and Díaz-Lage (2017). 
sentence I think that the only use I can *do with already made material ... (hit 1951). Obviously, the learner has made a wrong choice regarding the preposition because with does not collocate with make use.

On the other hand, there is also another example in which the structure of the sentence is not correct either, and we think it might help if we teach the learners about the structure of the right collocation. The sentence in hit 678 (e.g. related to the comment which have *done Maria) serves as an excellent example. Besides choosing the wrong verb for the delexical structure make a comment, the student collocates the verb before the subject, which is something completely wrong and inaccurate in English. In this sense, if we teach learners about the right delexical structure (e.g. make a comment), and we add the element that usually comes before (e.g. someone makes a comment), we might be helping the students to produce accurate and correct sentences. Obviously, the structure of the sentences in the corpus deserves a separate study and is not within the scope of this investigation. However, we contend that teaching the students about the right collocations together with some words that precede or follow them could certainly contribute to improving their speaking, writing and grammar skills.

The third group or category in the analysis of the first type of mistakes reflects the errors committed in causative structures that require make. Such structures are formed with causative verbs such as make, have, let and get and they are used to show that someone or something caused something to happen. Surprisingly in the corpus, the students make use of the high-frequency verb do with causative structures which are generally formed with make. In particular, the learners use do in order to create causative constructions that follow this pattern: make + object + adjective (e.g. make something easy). Examples of this type of error are shown in the table below.

Table 7. Miscollocations of $D O$ with causative structures.

\begin{tabular}{|c|l|l|c|}
\hline Hit number & \multicolumn{1}{|c|}{ Examples of miscollocations } & \multicolumn{1}{|c|}{ Correct form } & Student ID \\
\hline 669 & $\begin{array}{l}\ldots \text { a great source of information, } \\
\text { resources and activities that we } \\
\text { can use in our class to *do them } \\
\text { funner and different } \ldots\end{array}$ & $\begin{array}{l}\text { that we can use in our class } \\
\text { to make them more fun and } \\
\text { different }\end{array}$ & 25TOENICTA \\
\hline 926 & $\begin{array}{l}\ldots \text { we could *do more attractive } \\
\text { teaching } \ldots\end{array}$ & $\begin{array}{l}\text { make teaching more } \\
\text { attractive }\end{array}$ & 30TOENICTA \\
\hline 936 & $\begin{array}{l}\text { They are *doing my classes } \\
\text { much easier }\end{array}$ & $\begin{array}{l}\text { making my classes much } \\
\text { easier }\end{array}$ & 138TOENICT \\
\hline 1145 & $\begin{array}{l}\text { *doing of the TIC [sic] a } \\
\text { fantastic tool }\end{array}$ & $\begin{array}{l}\text { making a fantastic tool out } \\
\text { of ICT }\end{array}$ & 08TOENICTA \\
\hline 1632 & $\begin{array}{l}\ldots \text { it contributes to *do } \text { [sic] the } \\
\text { teacher's role easier } \ldots\end{array}$ & \begin{tabular}{l} 
make the teacher's role easier \\
\hline
\end{tabular} & 63TOENICTB \\
\hline
\end{tabular}

As observed in the table above, we have located 4 examples in which the high-frequency verb do is incorrectly used instead of make. However, there are two exam- 
ples in which the structure that follows after the verb (e.g. object + adjective) is correct and accurate. Such is the case of the sentence in hit 936 (e.g. they are *doing my classes much easier) and hit 1632 (e.g. it contributes to *do the teacher's role easier). Although the verb do cannot be used in these causative constructions (make needs to be used instead), the student follows the right pattern of causative structures with make that involve the pattern object + adjective. On the contrary, we have found two sentences in which the structure of the causative construction is not accurate. In the sentence, we could *do more attractive teaching (hit 926), the student does not only make a mistake by using do instead of make, but he/she also uses a wrong pattern for causative structures. The learner places the comparative adjective (e.g. more attractive) before the object (e.g. teaching) when it should be precisely the other way around (e.g. we could make teaching more attractive). However, in the sentence, *doing of the TIC [sic] a fantastic tool (hit 1145), the student follows the right order for causative structures (e.g. object + adjective), but he/she makes use of a preposition (of), which is not accurate in this construction. The result is a structure which is incorrect in English. First, because the high-frequency verb do cannot be used in this construction (make needs to be used), and second, because the preposition of does not collocate with a causative structure with make. Therefore, we can find two possibilities for this construction: either we produce a causative structure with make by following the pattern make + object + adjective (e.g. make ICT a fantastic tool) or we form a new structure with the pattern make something out of something/somebody, (e.g. make a fantastic tool out of ICT), which is considered as a phrasal verb by some dictionaries (LDOCE, 2019). This type of mistakes leads us to think that our students could also benefit from the teaching of other structures or constructions, whilst learning about collocations.

In addition, the influence of the students L1 is especially noticed in the sentences above because in Spanish causative structures are formed and used with the verb hacer. In this sense, the students are transferring the knowledge from their L1 to their L2 positively, but the problem lies in the fact that the English language has two different verb forms for hacer in Spanish (e.g. do and make). Therefore, the learners must choose between these two verbs, and this is quite confusing and problematic for them. As seen previously, the students chose the verb do in causative structures that require make, which is not a correct grammatical construction in English. However, the choice of make over do in causative structures does not respond to a logical explanation or rule, so in this case explaining the differences between make and $d o$ to our students would not help much. This is why we think that the reason behind these mistakes in causative structures is due to a low collocation awareness and competence (mainly because the learners do not seem to be aware of the use of make and its collocation with causative structures) and/or a low and poor mastery of the English language.

\subsubsection{Use of $D O$ as an alternative to OTHER VERBS}

The second type of mistake in the learner corpus makes reference to the use of the high-frequency verb do in sentences which require another verb. We identified 11 collocation errors out of 42 , which means that $d o$ is used incorrectly in $26.19 \%$ of the cases. The following examples illustrate the mistakes of this type. 
Table 8. Use of DO as an alternative to OTHER VERBS in the learner corpus.

\begin{tabular}{|c|c|c|c|}
\hline Hit number & Examples & Correct form & Student ID \\
\hline 8 & $\begin{array}{l}\text { I have never *done a class using } \\
\text { these tools. }\end{array}$ & given/prepared a class & 40TOENICTA \\
\hline 25 & $\begin{array}{l}\text { And what better than *doing a } \\
\text { skype with ... }\end{array}$ & having a skype lesson & 55TOENICTA \\
\hline 27 & $\begin{array}{l}\text {...you can go to the playground } \\
\text { and *do a Total Physical } \\
\text { Response game ... }\end{array}$ & $\begin{array}{l}\text { play a Total Physical } \\
\text { Response game ... }\end{array}$ & 102TOENICTA \\
\hline 30 & $\begin{array}{l}\text { I *did a website few years ago, } \\
\ldots\end{array}$ & created/developed a website & 30TOENICTA \\
\hline 358 & $\begin{array}{l}\text { But in my opinion, the forward } \\
\text { steps are *done by the pupils. }\end{array}$ & the forward steps are taken & 146TOENICT \\
\hline 473 & $\begin{array}{l}\text { We also use some apps with oor } \\
\text { [sic] personal tablets when we } \\
\text { *do engish }[\text { sic] corners ... }\end{array}$ & $\begin{array}{l}\text { when we work with English } \\
\text { corners }\end{array}$ & 05TOENICTA \\
\hline 728 & $\begin{array}{l}\text { Another game we *do is touch } \\
\text { the color... }\end{array}$ & another game we play & 125TOENICTB \\
\hline 1371 & $\begin{array}{l}\text {..I spent a couple of months } \\
* \text { doing school experiences in ... }\end{array}$ & $\begin{array}{l}\text { Undergoing/living/enjoying } \\
\text { school experiences }\end{array}$ & 02TOENICTA \\
\hline 1707 & $\begin{array}{l}\ldots \text { it was a pleasure to } * \text { do this } \\
\text { forum with all of you. }\end{array}$ & To share this forum & 102TOENICTA \\
\hline 1720 & $\begin{array}{l}\ldots \text { not all the education is } \\
\text { reliable to } * \text { do through the } \\
\text { internet... }\end{array}$ & $\begin{array}{l}\text { It is not always reliable to } \\
\text { carry out education through } \\
\text { the internet }\end{array}$ & 69TOENICTB \\
\hline 1830 & $\begin{array}{l}\text {... we * did two skypes with } \\
\text { them. }\end{array}$ & had two skype conversations & 137TOENICT \\
\hline
\end{tabular}

As we can see from the table above, the use of $d o$ in the examples is wrong. In this case, the students do not use the verb do instead of make. They make use of the verb do in sentences in which other different verbs are required (e.g. give, have, play, create, take, work, go through, carry out). If we take into consideration that some of the sentences require the verb hacer in Spanish, we can say that the students' first language (L1) is clearly interfering with the correct production of sentences in English. For example, in the sentences, * do a Total Physical Response game (hit 27) and another game we *do (hit 728), which in Spanish can be translated as hacer un juego de Respuesta Física Total (hit 27) and otro juego que hacemos (hit 728), the verb hacer is required.

Another example can be found in the sentence, it was a pleasure to *do this forum with all of you (hit 1707), which can be translated as fue un placer hacer este foro con todos vosotros into Spanish. The same happens in the sentences, and what better than *doing a skype with ... (hit 25) and we*did two skypes with them (hit 1830), which are also translated with the verb hacer into Spanish (e.g. y qué mejor 
que hacer un Skype / una sesión de Skype con ... (hit 25) and hicimos dos Skype / dos sesiones de Skype con ellos (hit 1830). In these cases, the students seem to be translating directly from their L1 into their second language (L2) and obviously they need the verbs do or make in English. Since it is clear that they do not understand the differences between $d o$ and make, they seem to select the verb that they think is more appropriate for the sentences they want to write. The result is a noticeable number of native-speaker like collocations which clearly resemble their L1. On the one hand, this implies a clear negative transfer from Spanish into English as other verbs are required when writing these sentences in English (e.g. play, share, have) and it is not possible to use do or make. However, on the other hand, this also suggests that the learners have a low collocational competence. In the examples above, the students do not seem to be aware of the verbs that collocate with certain words (e.g. according to the LTP Dictionary of Selected Collocations (1997), the Oxford Collocation Dictionary for Students of English (2007) and the BNC, the noun game (hit 27 and hit 728) collocates with verbs such as "have", "develop", "devise" and "play", and the noun forum (1707) collocates with "create" and "provide"). The students have used none of these verbs, and the result is the production of collocation errors with do which make sentences sound unnatural and awkward.

In addition to all these examples which require the verb hacer in Spanish, there are also some sentences in the learner corpus in which other verbs are needed both in Spanish and in English. Therefore, we cannot attribute the cause of collocation errors in these examples to L1 interference because even if the learners decide to translate directly from their L1 to English, the verb hacer, which is the equivalent of $d o$ and make in English, is not used in Spanish either. Such is the case of the sentences in hits $8,30,358,473,1371$ and 1720 . These examples contain different words that collocate with verbs other than do both in Spanish and in English (e.g. give/prepare (hit 8), create/develop (hit 30), take (hit 358), work (hit 473), undergo/live (hit 1371), and carry out (hit 1720). Of course, these are not delexical constructions, which means that the different nouns in the sentences (e.g. class, website, steps, corners, experiences, education) can collocate with other verbs as well, but they cannot combine with do (at least in these examples). This suggests once again that the students do not have enough knowledge regarding collocations and that they resort to the use of the high-frequency verb do to produce sentences which require other verbs. These deviations of do+noun collocations seem to be an effect of an overgeneralization, which is also indicative of the overuse of high-frequency verbs (do in this case) with nouns that do not generally collocate with them. These results are in agreement with other studies that point to an overuse of this type of verbs by learners of English (see Altenberg and Granger, 2001; Hasselgren, 1994; Källkvist, 1999).

\section{Conclusions and pedagogical implications}

Our findings verify that collocations continue to be an area of difficulty for the Spanish students studied in this research. As the data demonstrated, the students produce collocation errors with the high-frequency verb $d o$ when it is followed by noun ( $d i$ rect object) collocations. In particular, there are two major findings concerning the use of $d o$ with this type of collocations. On the one hand, the students collocate the high-frequency verb do with noun (direct object) collocations that usually require 
the verb make in three different cases: 1) when they use do with the meaning of creating and producing something new; 2) when they make use of $d o$ with delexical structures; and, 3) when they employ do with causative constructions. All these cases, meanings and constructions require the use of make, but the students choose to use the high-frequency verb $d o$ instead. According to our analysis, this implies basically two things: first, the students do not seem to know the differences between these two verbs, and second, the learners seem to ignore the strict collocational restrictions regarding delexical structures with make and the use of causative constructions with make, which also indicates that the students have a low collocation competence that is typically developed together with their five skills in the target language (CEFR, 2001). On the other hand, the learners in the corpus also collocate do with nouns (direct object) collocations that require the use of other verbs. From our point of view, these errors are the result of negative transfer from the students' mother tongue, a deficient knowledge regarding collocations and/or as a normal phase of interlanguage development.

All these aspects imply that collocations should be given due attention, especially if we are dealing with high-frequency verbs. Therefore, the results of our analysis have several pedagogical implications. As said previously, high-frequency verbs are usually acquired in the first stages of learning English, and they are not usually reinforced much in later stages of teaching. As Altenberg and Granger (2001: 190) point out, once this type of verbs have been taught, "they tend to be neglected". This is why it is very important that we continue to teach and reinforce the grammatical and lexical partnering of this type of verbs. Since the students investigated in this study have shown to be confused about the use of $d o$ and make, the first thing we should focus on is to carefully explain the basic differences between these two verbs in English (e.g. do is used for actions, obligations and tasks, although they do not produce a physical object; make is used for creating and producing something new). At the same time, multiple examples regarding combinations and collocations with the two verbs should be included as well (e.g. do homework, do a good job; make dinner, make a cup of tea). In this respect, it is essential to bear in mind that collocations are difficult for students precisely because their knowledge of the grammar and semantic rules are not enough when it comes to deal with collocations. Due to their natural arbitrariness, collocations must be learnt as a whole and cannot be built up using generative rules. These collocations should not only be taught in writing but should also be accompanied by visual support (e.g. displaying a video that contains different images that show the meaning of those expressions or collocations could be an excellent idea). Once the basic differences between these two verbs have been understood, we could move on to focusing on the different delexical constructions with $d o$ and make by following exactly the same procedure. After this, the students could identify those combinations or collocations in excerpts from short stories, newspapers and magazines, and write some sentences with them. They could also write some dialogues with these collocations and act them out in class.

In addition, instructors can also prepare communication activities in which students will have to describe situations, convey a message, give a short speech or retrieve missing information from their interlocutor based on given topics related to the learning outcomes of each teaching unit. It will also be convenient to help students build their list of vocabulary in context and encourage them to use these chunks in their writings and speeches to have more chances for mistakes and for 
the learning to be more effective. It is also recommended to share some anonymous authentic mistakes from students' writings for them to analyse and correct. This will raise their awareness about this type of errors and will encourage peer learning and corrections. It will also give a room for discussion and explanation by the instructor when necessary. In this way, we would be helping our students to reinforce their knowledge of collocations with do and make both in writing and speaking.

In line with this, some researchers recommend focusing on a selection of students' miscollocations (Sadeghi and Panahifar, 2013), including those which refer the learners' L1 (Altenberg and Granger, 2001; Sadeghi and Panahifar, 2013) in order to teach them properly. Likewise, studies also point out to the use of concordance exercises extracted from digital databases (Altenberg and Granger, 2001; Farrokh, 2012; Willis, 1998 (as cited in Farrokh, 2012) together with the use of collocation dictionaries and different exercises to identify collocations in texts from magazines and newspapers which can be used as authentic material (Farrokh, 2012). In other words, we should motivate our students to learn collocations, and as some scholars have suggested, we should teach vocabulary and lexis in collocation chunks rather than as isolated words (Lewis, 1993; Orosz, 2017).

\section{Limitations and further lines of investigation}

In the present study, some limitations were identified. Firstly, the scope of this study is limited to Spanish students taking the Degree in Early Childhood Education at Universidad Internacional de La Rioja (UNIR), and the data collected consist of written texts produced by these students; therefore, findings are by no means universal and cannot be generalized to all learners who use EMI. Secondly, as the students were not instructed to use the pattern verb (do) + noun (direct object) collocations, and sometimes they made use of structures in which the noun (direct object) appears before the verb, we also considered important to analyze those constructions because, as seen throughout our analysis, they also imply collocation errors. Thirdly, although this study focuses on noun (direct object) collocations with the high-frequency verb $d o$, it has been verified that students confuse do and make in free combinations of words, which, although they are not specifically collocations and they are lexical mistakes, have also been analyzed because the learners did not collocate $d o$ with the right and appropriate nouns or direct objects in those cases.

All in all, this study is a step towards analyzing a challenging aspect of the English language for Spanish learners, and we consider it essential to propose future lines of investigation. We suggest, as many other previous studies did, that the areas of the language where students are making more mistakes even at advanced levels should be given more consideration. In this way, we also want to encourage other studies of this style to highlight other problematic areas for Spanish learners of English. It could also be beneficial for language teaching and learning to have a comparison between native speakers' mistakes and our learners' ones. Also, it might be of very good help to have a study that trains students on the use of a selected number of collocations and test their competence before and after the training. Another research objective could also be the comparison of different teaching methodologies or different types of activities to see which work better than others. Make and $d o$ are also another rich field of investigation where a lot can be done to improve the use of these two verbs and their 
structures by our Spanish learners. Even though it might not be easy to collect oral data from students and compare their use of collocation in oral context to the written one, it can be an enriching experiment to see how students level varies or not in different communicative contexts. Another equally challenging research would possibly include a comparison between the performance of students from different levels' and test the correlation between the level of language mastery and the use of collocations. Any study that can shed light on the learning process and teaching methodology to encourage instructors to delve into new teaching adventures and share uncommon material and strategies with their students will surely be of great benefit to the field of SL and/or FL acquisition and Applied Linguistics in general.

\section{Acknowledgements}

This work has been carried out in the frame of the emerging research project "Detección y análisis del comportamiento lingüístico de producciones escritas de estudiantes universitarios" (Project reference: B0036-1617-104-ETEL. Universidad Internacional de La Rioja, 2016-2018).

\section{References}

Altenberg, Bengt and Granger, Sylviane (2001). The grammatical and lexical patterning of MAKE in native and non-native student writing. Applied Linguistics 22(2): 173-195.

Benson, Morton, Benson, Evelyn and Ilson, Robert (1986). The BBI combinatory dictionary of English: A guide to word combinations. Amsterdam: John Benjamins.

Biber, Douglas, Johansson, Stig, Leech, Geoffrey, Conrad, Susan and Edward Finegan, eds. (1999). Longman Grammar of Spoken and Written English. London: Longman.

Boers, Frank and Seth Lindstromberg (2009). Optimizing a Lexical Approach to Instructed Second Language Acquisition. New York: Palgrave Macmillan.

Brown, Dorothy F. (1974). Advanced vocabulary teaching: The problem of collocation. RELC Journal 5(2): 1-11.

Cambridge Online Dictionary (2019). Retrieved from https://dictionary.cambridge.org/es/

Common European Framework of Reference for Languages: Learning, Teaching, Assessment (2001). Retrieved from https://www.coe.int/en/web/common-european-framework-reference-languages

Duan, Manfu and Quin, Xiaohui (2012). Collocation in English teaching and learning. Theory and Practice in Language Studies 2(9): 1890-1894. DOI:10.4304/tpls.2.9.1890-1894

Durrant, Philip Lee (2008). High Frequency Collocations and Second Language Learning. (Unpublished Doctoral dissertation). Nottingham: University of Nottingham.

Ellis, Nick C. (1996). Sequencing in SLA. Studies in Second Language Acquisition 18: 91126.

Farrokh, Parisa (2012). Raising awareness of collocation in ESL/EFL classrooms. Journal of Studies in Education 2(3): 55-74. DOI:10.5296/jse.v2i3.1615

Firth, John Rupert (1957). Papers in linguistics. London: Oxford University Press.

Gyllstad, Henrik (2007). Testing English Collocations: Developing Receptive Tests for Use with Advanced Swedish Learners. (Doctoral dissertation, Lund University, Sweden). Retrieved from https://lup.lub.lu.se/search/ws/files/5893676/2172422.pdf. 
Hasselgren, Angela (1994). Lexical teddy bears and advanced learners: a study into the ways Norwegian students cope with English vocabulary. International Journal of Applied Linguistics 4: 237-60.

Herbst, Thomas (1996). What are collocations: Sandy beaches or false teeth? English Studies 77(4): 379-393.

Hill, Jimmie (2000). Revising priorities: from grammatical failure to collocational success. In Lewis, Michael (Ed.), Teaching collocation: Further developments in the lexical approach (pp. 49-50). Hove/UK: Language Teaching Publications.

Hill, Jimmie and Lewis, Michael (1997). LTP dictionary of selected collocations. Kentucky: Cengage Learning, Inc.

Huddleston, Rodney and Pullum, Geoffrey K. (2002). The Cambridge Grammar of the English language. Cambridge: Cambridge University Press.

Hugon, Claire (2008). High-frequency verbs: starting block or stumbling block for advanced L2 communication? Insights from native and learner corpora. In G. Rawoens, red., Taal aan den lijve. Het gebruik van corpora in taalkundig onderzoek en taalonderwijs (pp. 69-98). Gent: Academia Press.

Jaén, María Moreno (2007). A corpus-driven design of a test for assessing the ESL collocational competence of university students. International Journal of English Studies 7(2): 127-147.

James, Carl (1998). Errors in language learning and use: Exploring Error Analysis. London: Taylor \& Francis.

Juknevičienė, Rita (2008). Collocations with High-Frequency Verbs in Learner English: Lithuanian Learners vs Native Speakers. Kalbotyra 59.3: 119-127.

Källkvist, Marie (1999). Form-class and task-type effects in learner English. A Study of Advanced Swedish Learners. Lund: Lund University Press.

Károly, Adrienn (2005). The importance of raising collocational awareness in the vocabulary development of intermediate level learners of English. Eger Journal of English Studies V: 58-69.

Lewis, Michael J. (1993). The lexical approach: The state of ELT and the way forward. Hove, England: Language Teaching Publications.

Lewis, Michael J. (1997). Implementing the lexical approach: Putting theory into practice. England: Language Teaching Publications.

Lewis, Michael J. (2000). Language in the lexical approach. In Michael, Lewis, ed., Teaching collocation: Further developments in the lexical approach (pp. 133-134). London: Language Teaching Publications.

Luzón, María José (2011). Exploring atypical verb+noun combinations in learner technical writing. International Journal of English Studies 11(2): 77-95.

Macmillan Dictionary (2019). Retrieved from https://www.macmillandictionary.com/.

Martynska, Małgorzata (2004). Do English language learners know collocations? Investigationes Linguisticae 11: 2-12.

McCarthy, Michael (2018, January 4). Why good language teachers should take collocations seriously [Web log post]. Retrieved from http://www.cambridge.org/elt/blog/2018/01/04/ why-good-language-teachers-should-take-collocations-seriously/.

McCarthy, Michael, O’Keeffe, Anne, and Walsh, Steve. (2010). Vocabulary matrix: Understanding, learning, teaching. Boston/MA: Thomson Heinle Publications.

Nation, I.S.P. (2001). Learning vocabulary in another language. Cambridge: Cambridge University Press.

Nesselhauf, Nadja (2003). The use of collocations by advanced learners of English and some implications for teaching. Applied Linguistics, 24(2): 223-42. 
Nesselhauf, Nadja (2004). What are collocations? In D. Allerton, N. Nesselhauf, and P. Skandera, eds., Phraseological units: Basic concepts and their application (pp. 1-21). Basel: Schwabe.

Nesselhauf, Nadja (2005). Collocations in a learner corpus. Amsterdam: John Benjamins.

O'Dell, Felicity and McCarthy, Michael (2008). English Collocations in Use: Advanced. Cambridge: Cambridge University Press.

Orosz, Agnes (2017): Helping Spanish speakers better understand and use verb-noun collocations in English. MEXTESOL Journal 41(3): 1-9.

Oxford Collocations Dictionary for Students of English (2002). Oxford: Oxford University Press.

Palmer, Harold Edward (1933). Second interim report on English collocations. Tokyo: Kaitakusha.

Parrott, Martin (2010). Grammar for English language teachers. (2nd ed.). Cambridge, UK: Cambridge University Press.

Qader, Daban Saber (2018). The role of teaching lexical collocations in raising EFL learners' speaking fluency. Journal of Literature, Language and Linguistics 46: 42-53.

Sadeghi, K., and Panahifar, F. (2013). A corpus-based analysis of collocational errors in the Iranian EFL learners' oral production. The Journal of Teaching Language Skills 4(4): 53-78.

Shitu, Fatima Muhammad (2015). Collocation errors in English as second language (ESL) essay writing. International Journal of Cognitive and Language Sciences 9(9): 32703277.

Sinclair, John (1990): Collins cobuild English grammar. London: Collins.

Sinclair, John (1991). Corpus, concordance and collocation. Oxford: Oxford University Press.

Torrado-Cespón, Milagros and Díaz-Lage, José María (2017). Error Analysis and Interlanguage in the Use of the Term 'ICT' in an Online Learner Corpus. Complutense Journal of English Studies, 25: 105-123. http://dx.doi.org/10.5209/CJES.56354

Wray, Alison (2000). Formulaic sequences in second language teaching: Principle and practice. Applied Linguistics 21(4): 463-489.

Wu, Shaoqun (2010). Supporting collocation learning. (Doctoral dissertation, University of Waikato, Hamilton, New Zealand). Retrieved from https:/www.cs.waikato.ac.nz/ ihw/ $\mathrm{PhD}$ theses/Shaoqun_Wu.pdf

Yamashita, Junko and Jiang, Nan (2010). L1 influence on the acquisition of L2 collocations: Japanese ESL users and EFL learners acquiring English collocations. TESOL Quarterly 44(4): 647-668.

Ye, Hong (2014). A study of collocation errors among Chinese learners of English (with reference to Chinese college students of Tongji University in China). (Doctoral dissertation, University of Malaya, Kuala Lumpur). Retrieved from http://studentsrepo.um.edu. my/4698/1/YE_HONG.pdf

Zhou, Xiujuan (2016). A corpus-based study on high frequency verb collocations in the case of "Have". International Forum of Teaching and Studies 12(1): 42-50.

Zinkgräf, Magdalena (2008). V+N miscollocations in the written production of university level students. Estudios de Lingüística Inglesa Aplicada 8: 91-116. 